\title{
Ingen panik - Iran kan balanceres
}

\author{
Ali Rahigh-Aghsan Adjunkt, PhD, Institut for Samfund og Globalisering, Roskilde Universitet ${ }^{1}$
}

Iran anses af mange som en voksende magtfaktor i Mellemøsten, der i stigende grad truer den regionale og endda globale sikkerhed. Irans hårde magt (konventionelle og ikke-konventionelle kapabiliteter) og bløde magt (den politiske shi'a islam) betragtes som fundamentet til udviklingen af Irans stormagtsstatus og dets indflydelse/trussel i regionen. Dette fundament er imidlertid skrøbeligt, og der er ingen grund til panik. Selv et Iran med atomvåben kan inddæmmes og balanceres og Iran's bløde magt er meget begrænset. At bombe Iran vil derfor være en stor fejltagelse.

\section{Introduktion}

At Irans magt er voksende er de fleste Mellemøsteksperter enige om. Mens det er de færreste der vil gå så langt som til at beskrive Iran som en trussel mod verdensfreden, som medlemmer af både Bush og Obama administrationerne har gjort (Global Research 2010, Whitehouse 2010 and Lee Myers 2008), så er de fleste enige om at Irans indflydelse i regionen har været stigende det sidste årti, og at det er en udvikling der ikke ser ud til at stoppe foreløbig. Det er efterhånden de færreste, der tror på, at Irans atombombeprogram kan stoppes, og forventningen er at et Iran med atomvåben vil få endnu mere magt og indflydelse end det har i dag. Det er på den baggrund, at debatten om at bombe Iran's atomprogram atter blussede op henover sommeren i USA (Etzioni 2010).

Denne artikel vil argumentere for at Irans magt er stærkt overvurderet, og at regimet sagtens kan balanceres og inddæmmes - også selvom det skulle få atomvåben. Argumentet har tre trin. Første del præsenterer den konventionelle visdom som siger at Iran er på vej til at blive en regional stormagt. Anden del piller dette argument fra hinanden ved at vise at Irans hårde og bløde magt er stærkt overvurderet. Tredje del argumenterer for at Iran kan inddæmmes og at et atomkapløb i Mellemøsten kan undgås. Artiklen afrundes med en kort konklusion til slut.

\section{Iran som den nye magtfaktor i Mellemøsten}

Argumentationen for, at Irans magt stiger hviler groft sagt på en 'hård magt' og en 'blød magt' komponent (Nye 1990). Hård magtskomponenten fokuserer på Iran's voksende evne til at påtvinge andre sin vilje gennem brug af alliancer og militære kapabiliteter (Inbar 2006, Eisenstadt 2001, McInnis 2005, Rubin 2006 og Posen 2006). Blød magts perspektivet har fokus på Iran's evne til at inspirere og agere religiøs og ideologisk rollemodel i sin forklaring på Irans opstigen (Nasr 2004, 2007, Takeyh 2008, Salem 2007og Lowe and Spencer 2006), og tilsammen tegner de to perspektiver et billede af et Iran i fremmarch, der er meget svært at stoppe. ${ }^{2}$

Hård magt-perspektivet peger på at Iran har øget sin relative magt i regionen ved at øge sin kapacitet til asymmetrisk krigsførsel og ved at intensivere sit samarbejde med Syrien og militante islamistiske grupper, især $\mathrm{Ha}$ mas og Hizbollah. Hertil kommer at Iran har nydt godt af at USA har fjernet Taleban regimet i Afghanistan og Saddam Hussein regimet i Irak som begge var fjendtligt indstillet overfor Iran. USA's problemer med at stabilisere disse lande har også givet Teheran vigtige kort på hånden i forhold til USA, da Irans evne til at destabilisere begge lande gør det svært for USA at lægge effektivt pres på Iran for at opgive dets atomvåbenprogram.

I hård magt-perspektivet udgør Irans voksende militære kapacitet en voksende trussel. En stat der øger 
sin magt forventes at ville øge sin sikkerhed og magt og Teheran opfattes derfor enten som status-quo orienteret magt det ønsker at øge sin sikkerhed og overlevelsesevne (afskrækkelse af USA) (Chubin 2008), eller som en revisionistisk stat, der stræber efter regionalt hegemoni og søger at eksportere sin islamiske revolution.

Ifølge Michael Eisenstadt har revolutionære Iran lagt stor vægt på sine militære kapabiliteter, specielt de konventionelle (nukleare, kemiske og biologiske). Dette skyldes at Irans gejstlige ledere er af den opfattelse at „the fate of the worldwide Islamic community depends on Iran's ability to transform itself into a military power that can defend and advance the interests of that community" (Eisenstadt 2001, 18). Inbar går et skridt videre og argumenterer at „Iran's nuclear program was initiated with the ability to play the role of a great power in World affairs" (Inbar 2006, 3). Ifølge realister, skal det iranske atomprogram betragtes som en alvorlig trussel, da et atombevæbnet Iran vil resultere i en nuklear dominoeffekt i form af et nyt våbenkapløb i regionen (McInnis 2005). Desuden frygter nogle analytikere, at Iran vil donere atomvåben til terrorgrupper, der vil bruge disse mod Israel, eller at Iran vil bruge atomvåben imod sine egne borgere i tilfælde af, at et internt oprør truer med at omstyrte regimet (McInnis 2005). I hård magt-perspektivet er der ikke tiltro til, at hverken den amerikanske eller europæiske indsats vil begrænse og balancere den voksende iranske indflydelse. Begrundelsen er, at man anser den anvendte diplomatiske strategi for at have slået fejl ved udelukkende at have resulteret $i$, at Iran har fået mere tid til at udvide deres magtposition (Rahigh-Aghsan og Jakobsen 2010). Økonomiske og politiske sanktioner anses som lige så ineffektive på grund af russisk og kinesisk modstand, og da et eventuelt militært luftangreb betragtes som en højrisiko strategi, der næppe er i stand til at forhindre Iran i at udvikle deres atomvåben, anskues det ifølge hård magtperspektivet som værende nærmest umuligt at forhindre Irans voksende magtposition (Posen 2006). Derudover forventes Iran at fortsætte styrkelsen af sin militær kapabilitet og udfordre USA's indflydelse i Mellemøsten, og det er blevet populært at hævde at USA har mistet evnen til at sætte dagsordenen og bestemme udviklingen i regionen (Malmvig 2010).

Blød magts-perspektivet forklarer Irans voksende magtposition med henvisning til religiøse og ideologiske faktorer. Ray Takeyh og Vali Nasr er de ledende eksponenter for denne tankegang, og deres artikler i henholdsvis Middle East Journal, Iran's New Iraq, og Washington Quarterly, Regional Implications of Shi'a Revival in Iraq er førende litteratur inden for denne tankegang. Ifølge denne synsvinkel er den væsentligste årsag til Irans voksende regionale magt oprettelsen af en shiitisk-domineret regering i Bagdad samt Hizbollah's stigende indflydelse i Libanon (Nasr 2007, 13). Blød magtskomponenten ser med andre ord etableringen af den såkaldte 'arch of Shi' ism' eller den 'Shi' ite cresent' som værende nøglen til Irans voksende magt. Som Nasr udtrykker det:

„The Iranian revolution of 1979 initially mobilized the Shi'a identity and emboldened the Shi'a masses to follow the Iranian lead, flexing their muscles and asserting their rights elsewhere in the region. The Iranian revolution not only showed the Shi'a a path to power but also provided powerful financial, moral, and organizational support in the Shi'a struggles for rights and representation. ...Shi'a had championed secular nationalist causes and looked to Pan-Arabism or leftist ideologies to bridge the sectarian divide and include them in the political mainstream, in the 1980s many joined the ranks of distinctly Shi'a political Movements“" (Nasr 2004, 9).

Sammenbruddet af den pan-arabiske nationalisme ses som en anden central faktor bag Irans voksende regionaldominans. I følge Barry Rubin, er den arabiske nationalisme, hvis man ser bort fra den propagandistiske retorik, brudt sammen især i internationale sammenhæng. Der er ingen arabisk verden længere. Der er ikke en eneste arabisk stat, der har nogen reel indflydelse på de andre i dag. Egypten er optaget af interne problemer, Syrien er isoleret, og Irak har svært ved at definere sig selv som arabisk. Kun Iran har noget at tilbyde ideologisk, og samtidig de eneste, der er i stand til at fremme deres indflydelse på tværs af grænser (Rubin 2006, 145).

Den iranske evne og vilje til at udfylde dette tomrum med sin egen ideologiske model, er blevet gjort til en rollemodel for muslimer over hele verden. Dette kan ses hos den Islamiske Salvation Front (FIS) i Algeriet, Den Nationale Islamiske Bevægelse i Sudan, Hizbollah, Hamas og Islamisk Jihad i Palæstina og Libanon, Det Muslimske Broderskab i Jordan, al-Nahda partiet i Tunesien, og Jihad-gruppen i Egypten. I blød-magt perspektivet hænger den største trussel fra Iran samme med det hurtige skift til fordel for Iran i den ideologiske magtbalance mellem shi'aer og sunnier i Mellemøsten. Dette vil kunne øge risikoen for yderligere ustabilitet og i ekstreme tilfælde borgerkrig (Salem 2007). Udbruddet af vold mellem sunnier og shi'aer i både Irak og Libanon ses som en direkte følge af denne magtforskydning. Ligeledes er de sunnimuslimske regimer i Saudi-Arabien, Bahrain, Oman, Kuwait, Qatar og Forenede Arabiske Emirater (UAE) meget bekymrede over dannelsen af en shi'a domineret regering 
i Irak, hvilket vil styrke den shiitiske bevægelse i deres egne samfund (Takey 2008, 25).

I blød magt-perspektivet, er Irans status som stormagt i Mellemøsten udelukkende relateret til politisk islam a lá Iran (Shi' ism). Set i denne sammenhæng formodes Iran at være den mest magtfulde aktør i regionen; selv uden atomvåben.

\section{Hvorfor Irans magt og indflydelse er overdrevet}

I det følgende vil jeg argumentere for at disse fremherskende opfattelser lider under en række mangler, der tilsammen resulterer i en overdrivelse af stigningen i Irans magt og dermed af omfanget af landets trussel for regional og international sikkerhed.

\section{Irans militærmagt er blæst ud af proportioner}

De, som argumenterer for Irans voksende militære magt, undlader generelt at placere Iran i en regional sammenhæng. Ligeledes overdriver de landets offensive potentiale og ignorerer de konventionelle styrkers ringe kvalitet. Hvis man alene ser på kvantitet, synes det iranske militær at nyde fordele i både mandskab og materiel. Billedet ændrer sig imidlertid, når forsvarsudgifterne og kvaliteten af de væbnede styrker tages i betragtning. Hvad angår forsvarsudgifter, er Iran klart udkonkurreret af de seks medlemmer af Den Persiske Golfs Samarbejdsråd (GCC): Bahrain, Kuwait, Oman, Qatar, Saudi-Arabien og Forenede Arabiske Emirater (UAE). Tilsammen brugte disse lande 7,5 gange mere på deres forsvar end Iran i perioden 1997-2007. Forskellen er endnu mere dramatisk, når sammenligningen angår anskaffelser af våben. GCC-landene brugte 15,6 gange mere på våben end Iran i løbet af 19882007 (Rahigh-Aghsan og Jakobsen 2010). Således har de væbnede styrker i GCC-landene langt bedre udrustning end Iran. GCC-landene har henholdsvis 495 højteknologiske kampfly og 1816 kampvogne sammenlignet med Irans 55 kampfly og 730 kampvogne. Saudi-Arabien alene har flere højteknologiske kampfly og kampvogne end Iran. GCC-landene har i alle kategorier også flere større flådefartøjer end Iran bortset fra ubåde, hvor Iran har 3 og GCC-landene ingen (Cordesman 2008, 4-5). Ligeledes blegner indtrykket af Irans stående hær noget, når man kigger på kvaliteten. Irans militære styrker består af 545.000 aktive personer hvoraf 220.000 er 18 -måneders værnepligtige, som kun modtager 3 måneders militær uddannelse. Til sammenligning samarbejder GCC-landene med førende militære magter som Frankrig, England og USA på træningsområdet, hvilket styrker militæret i forhold til Iran, der ikke er omfattet af et sådan samarbejde.

Iran har med andre ord en konventionel kapacitet til at afskrække andre stater $i$ regionen fra at angribe landet, men landet har samtidigt begrænsede offensive evner grundet dårlig kvalitet af de militære styrker og udstyr samt logistiske problemer. De bedste offensive kort er den iranske flådes evne til, på trods af USA's modstand, at afspærre Hormuz-strædet i op til flere uger ad gangen samt den iranske 125.000 mand store revolutionsgarde (IRGC), der udgør en potent kapacitet til asymmetrisk krigsførelse og terroraktiviteter. Således kan man betragte Irans bestræbelser på at udvikle ballistiske missiler og ikke-konventionelle våben som en mulig kompensation for den konventionelle militære svaghed. Det skal her fremhæves, at et af de største missil-programmer i Mellemøsten er i hænderne på Iran. Iran har desuden købt nordkoreanske Scud-Bs, Scud-Cs og No-dong ballistiske missiler, som er blevet anvendt til at udvikle de iranske Shahab-1, -2, og -3 missiler. Shahab-3 missilet, der blev taget i brug i 2003, har en rækkevidde på $1.300 \mathrm{~km}$ og er i stand til at nå Israel. Men Iran er fortsat engageret $i$ et aggressivt missil-udviklingsprogram, der omfatter udvikling af ballistiske missiler med større rækkevidde, krydsermissiler, og en bedre rumopsendelses- kapacitet. Den første satellit, som Iran satte i kredsløb i februar 2009, skønnes at være i stand til at bære et ton nyttelast og samtidig have en rækkevidde på $1.500-1.800 \mathrm{~km}$ (IISS 2009).

Alt i alt, kan det ud fra et bredt militært perspektiv dermed hævdes, at den iranske konventionelle kapacitet samt dens militære offensive kapacitet, er præget af en lang række begrænsninger. Disse begrænsninger hænger nøje sammen med en række faktorer; landets alvorlige økonomiske problemer, den vestlige våbenembargo, mangel på en veluddannet militærstyrke, et effektivt logistik og kommando-system, samt vanskeligheder i forbindelse med landets militære struktur (professionel hær vs. revolutionsgarden og Basij). Her kan der, på baggrund af gennemgangen, hævdes, at hård magtskomponentens antagelse om at Iran udgør en voksende militære magt er stærkt overdrevet. Man kan tage skridtet videre ved at argumentere at hård magtskomponentens vurdering/ analyse af Irans konventionelle kapacitet fører til forkerte policy implikationer, og dermed til argumentet om at at Irans militære kapaciteter udgør en alvorlig trussel 'ikke blot til Mellemøsten, men til hele verden' (Inbar 2006, McInnis 2005 og Rubin 2006).

Iran er som sagt mistænkt for at forsøge at anskaffe atomvåben, og det anslås, at de vil nå status som atommagt engang i perioden mellem 2011 og 2015. Iran selv benægter at have et militært atomvåbenprogram, men det Internationale Atomenergiagentur (IAEA) er ikke overbevist om, at det iranske atomprogram udelukkende tjener fredelige formål. Det er en kendsgerning, at Irans nukleare kapacitet højner Irans regionale stormagtsstatus, og herigennem øger landets prestige i den muslimske 
verden. Det er også givet, at hvis Iran opnår høj nuklear teknologiske faciliteter ('technological threshold'), ville det gøre dem i stand til at producere beriget uran på højt niveau, hvilket er anvendeligt til atomsprænghoveder ('point of no return'). Derved kan Irans a-våben i modsætning til konventionelle kapaciteter muligvis være med til at holde USA fra døren. Men selvom Iran fortsat vil afskrække angreb udefra, vil landets offensive potentiale være begrænset, idet brugen af atomvåben, i andre situationer end selvforsvar eller støtte til terrororganisationer, vil medføre en stor risiko for repressalier. Som Waltz har udtrykt det:

'[Iran] certainly does not gain much ability to act in a conventional way because it has nuclear weapons. Again nuclear weapons have one purpose and only one purpose, and that's deterrence' (Waltz 2007, 145).

Desuden vil den politiske værdi ved at anskaffe atomvåben også være begrænset, da det sandsynligvis vil udløse en aktiv balancering fra stormagter (så kaldt permanent P5+1 (Tyskland, Frankrig, England, Kina, Rusland og USA)) samt andre regionale stormagter i Mellemøsten.

\section{Irans bløde magt er stærkt overdrevet}

Irans stigende bløde magt sammen med det ideologiske shi'a-sunni magtbalanceskift samt Irans evne, som følge af sammenbruddet i den arabiske nationalisme, til at præsentere sig selv som leder af alle muslimer i det bredere Mellemøsten. Et centralt problem ved denne fortolkning er den enorme overdrivelse af shi'a-islam som magtressource. Som udgangspunkt er der kun 10-15 procent af alle verdens muslimer, som er shi'a muslimer, og samtidig er Iran ikke anerkendt som en leder eller rollemodel inden for det shiitiske samfund i Mellemøsten. Der er faktisk kun et par procent af shi'a muslimerne, som følger det iranske lederskab. Eksempelvis fulgte shi'a muslimerne i Den Persiske Golf-region, Centralasien og Kaukasus, herunder Bahrain, Aserbajdsjan, Tadsjikistan, Turkmenistan og endda i Pakistan og Afghanistan aldrig den iranske model, der er baseret på Velayat-e Faqih doktrinen, hvor den politiske magt er i hænderne på de gejstlige. Irans ubetydelige indflydelse indenfor shi'a samfundet er formentlig bedst illustreret ved, at ingen andre muslimske lande siden den iranske revolution i 1979 har fulgt den iranske model. Siden Khomenei døde i 1988 har de iranske bestræbelser på at eksportere sin model til andre shi'a muslimske lande i Mellemøsten, Centralasien og Kaukasus været en alvorlig fiasko, bortset fra Hizbollah i Libanon (Nasr 2004, 10-15).
I modsætning til blød magts-perspektivets opfattelse, har genkomsten af et shi'a-domineret Irak ikke i betydelig grad ændret den ideologiske magtbalance til Irans fordel. For eksempel har den mest magtfulde shiitiske præst i Irak, Storayatollah Ali al-Sistani, aldrig troet på Velayat-e Faqih doktrinen, og han anser det som en ren iransk variant af den islamiske jurisprudens, der ikke gør sig gældende i Irak. Endvidere har Irans indflydelse i Irak været på tilbagegang siden partiet ISCI (Islamic Supreme Council of Iraq), under ledelse af Ayatollah Abdul Aziz al-Hakim samt Dawa Partiet under ledelse af premierminister Nouri al-Maliki, brød med Iran og besluttede, at det var i deres bedste interesse at give USA mulighed for at lægge militært pres på Muqtada al-Sadr og hans Mahdi-hær. Den politiske og militære marginalisering af al-Sadr medførte yderligere begrænsninger for Irans indflydelse i Iraks udvikling. Denne kendsgerning blev mere synlig, da det irakiske parlament med Dawa og ISCI i spidsen i november 2008 stemte for den strategiske rammeaftale og tilbagetrækningsplanen med USA på trods af hårdt lobbyarbejde og pres fra Iran. I stedet for et skift i den sunni- og shiamuslimske ideologiske magtbalance, kan en shi'a oprejsning i Irak forstærke de interne religiøse stridigheder blandt shi'a-muslimer, hvor det irakiske Najaf begynder at udfordre det iranske Qom som centrum for den shiitiske teologi.

Endelig er det også forkert at betragte Iran som den eneste islamiske model efter sammenbruddet af den panarabiske nationalisme. Iran er godt nok populær hos mange arabere på grund af sin radikale modstand mod USA og støtte til grupper, der bekæmper Israel. Man må dog ikke glemme, at Irans kulturelle, sproglige, etniske og religiøse sammensætning står i modsætning til de fleste sunni-muslimer i Mellemøsten. Opdelingen i persisk vs. arabisk og sunni/wahhabisme vs. shi'a-islam sætter alvorlige begrænsninger for den iranske indflydelse. Irans intensive indsats for at fremstå som en pan-islamisk leder kan ikke ændre det faktum, at Iran fortsat er „the odd man out" $\mathrm{i}$ den arabiske verden (Rahigh-Aghsan og Jakobsen 2010). Iransk popularitet har, i forbindelse med landets rolle under Hizbollahs krig mod Israel i 2006, vist sig at være kortvarig. Siden 2007 har der også været klare tegn på, at den arabiske støtte til Iran er faldet mærkbart, idet Iran blev betragtet som medansvarlig for den eskalerende sekteriske vold i Irak. Den omstændighed, at Irans største transnationale arabiske medie, Al Alam, har meget lavere seertal end sine pan-arabiske konkurrenter, Al Arabiya og Al Jazeera, er endnu et tegn på, at Irans indflydelse i den arabiske verden er blevet overdrevet (Green, Wehrey og Wolf 2009, 34-36).

Det forekommer usandsynligt, at Ahmadinejads energiske forsøg på at placere Iran som leder af den ara- 
biske og muslimske verden vil kunne ændre ved situationen. Det ser tværtimod ud til at have den stik modsatte effekt, da Ahmadinejads aggressive Mellemøstpolitik har fåt Bahrain, Egypten, Jordan, og Saudi-Arabien til at slå hårdere ned på de shiamuslimske grupper i deres samfund (Abu-Nasr 2009). Desuden har den saudiske regering i tæt samarbejde med Wahhabister fået opbygget et gejstligt netværk af seminarier, moskeer, uddannelsesinstitutioner, prædikanter, aktivister, forfattere, journalister og akademikere, der søger at understøtte sunni-identiteten og eliminere Irans ideologiske indflydelse.

I betragtning af at Saudi Arabiens BNP er mere end $60 \%$ større end Irans, er det ikke overraskende, at saudiske analytikere vurderer, at Teheran ikke er i stand til at realisere sine regionale ambitioner eller opretholde sin støtte til andre lande med et shiitisk flertal (Nawaf 2006, 9). Endelig kan vi nævne, at Tyrkiets sekulære model siden 1900'erne, i kølvandet på de intense magtkampe mellem iranske Shi'aer og saudiarabiske sunnier/Wahhabister, har fremstået som den dominerede drivkraft bag udbredelsen af politisk islam som styremodel i den islamiske verden (Yavuz 2009).

\section{Balancering og inddæmning er en reel mulighed}

Hvorvidt Iran vil anskaffe sig atomvåben eller ej er uvist. Det er også uvist, hvorvidt Iran kan overtales til at opgive at anskaffe den teknologi, der bruges til at bygge atombomber. Men den hidtidige mangel på fremskridt i atomforhandlingerne med Iran er ikke ensbetydende med, at Irans voksende magt ikke kan balanceres, og at et atomvåbenkapløb ikke kan afværges. Uanset om Iran får atomvåben eller ej, vil en effektiv balancering og inddæmning som udgangspunkt, kræve en fælles militær, $ø$ konomisk og politisk indsats fra de vestlige lande og GCC-landene. Balancering og inddæmning forstås her i den gængse betydning som strategier, der tager sigte på at forhindre en fjendtlig stat $\mathrm{i}$ at true sine omgivelser (hård magt) eller udbrede en uønsket ideologi eller politik (blød magt). Balancering betjener sig af militære midler og kan tage form af militær oprustning (intern balancering) og indgåelse af forsvarsalliancer for at imødegå aggression (extern balancering) (Waltz 1979). Inddæmning defineres bredere som indgåelse af alliancer og andre former for samarbejde med det formål at isolere en fjende økonomisk, politisk og kulturelt.

Derigennem kan man forsøge at overbevise Iran om, at det er uhensigtsmæssigt at anvende konventionel og asymmetrisk militærmagt til at skræmme eller undergrave andre landes stabilitet. Uanset om Iran får atomvåben eller ej, vil Irans evne til at støtte ikke-statslige aktører som Hamas, Hizbollah, Palæstinensisk Islamisk Jihad og Taliban, samt at udføre asymmetriske krige, fortsat være Irans vigtigste instrument til at påvirke den politiske udvikling i regionen. Besiddelse af atomvåben giver Teheran mulighed for at optrappe sin støtte til militante grupper samt at brug asymmetriske strategier uden frygt for militær gengældelse. Dog vil besiddelse af atomvåben ikke automatisk resultere i øget politisk indflydelse, idet trusler om brugen af atomvåben er vanskelig at bruge i andre situationer end selvforsvar (Rahigh-Aghsan og Jakobsen 2010). Hertil kommer, at en officielt erklæret iransk atombombe også vil give Irans regionale rivaler et større incitament til balancere (både intern og extern) og inddæmme regimet.

Langt de fleste analytikere mener ikke, at balancering og inddæmning er en reel mulighed set i lyset af GCClandenes manglende vilje til at konfrontere Iran, samt deres modstand mod enhver form for magtanvendelse over for Iran. Imidlertid er der fire forhold, som taler for, at balancering og inddæmning kan lade sig gøre.

For det første har GCC-landenes forsigtige retorik og udtalte modstand mod forebyggende angreb på Iran fået mange til at overse, hvor aktivt landene allerede balancerer Iran. Den mangeårige saudiarabiske indsats for at minimere den iranske bløde magt er allerede blevet nævnt ovenfor. Den er blevet forstærket i takt med Irans voksende magt, og Saudi Arabien og Bahrain har strammet kursen overfor deres shiamuslimske mindretal for at forhindre iransk infiltration. GCC's beslutning i 2006 om at indlede en fælles undersøgelse af den 'fredelige nukleare teknologi' var ligeledes et udtryk for blød diplomatisk balancering med det klare formål at fortælle Iran, at GCC ville svare igen med samme mønt, hvis Iran udviklede atomvåben (Katzman 2008). GCC har også iværksat hård militær balancering (intern balancering) ved at overhale Iran på det konventionelle område. GCCs forsvarsudgifter er fortsat med at stige kraftigt i de seneste år, og prioriteringen af anti-ballistiske missilkapaciteter viser en voksende bekymring over truslen fra Iran (Jentleson 2007). Alle GCC-lande er i færd med at erhverve eller opgradere avancerede patriotmissilsystemer (PAC3), og den amerikanske kongres godkendte ligeledes salget af de meget avancerede luftforsvars-anti-missilsystem (THAAD) til Forenede Arabiske Emirater (UAE) i begyndelsen af 2009 (Fitzpatrick 2008). Denne oprustning er ledsaget af et tættere militært samarbejde med USA, Storbritannien, Frankrig og NATO, og GCC-Amerika samarbejdet er blevet intensiveret som følge af 'Gulf Security Dialogue', der blev iværksat i 2006. Selvom dette initiativ har gjort små fremskridt med hensyn til at etablere et tættere samarbejde mellem GCC-landene selv, har det hovedsageligt ført til et tættere forsvarssamarbejde 
mellem USA og GCC (Pollack 2009). Frankrig etablerede desuden sin første militære base i den Persiske Golf i Abu Dhabi i UAE i 2008, og senere samme år holdt NATO for første gang fælles sømilitære øvelser med fire GCC medlemmer (Bahrain, Kuwait, Qatar og UAE) (Bennhold 2008).

For det andet har valget af USA's nye præsident, Barack H. Obama, forbedret mulighederne for at inddæmme og balancere Iran på tre måder. Det har gjort det lettere for både arabiske og europæiske lande at samarbejde med USA uden, at det udløser utilfredshed på hjemmefronten. Det skyldes både at Obama var en klar modstander af Irak-krigen, og at han er i gang med at trække de amerikanske soldater ud af Irak, samt at han har forsøgt at gå i dialog med Syrien og Iran. Det hjælper desuden, at den nye præsident opfattes som mindre tilbøjelig til at godkende et forebyggende angreb mod Iran end den tidligere Bush administration. For det andet har Obama administrationens forsøg på at engagere Iran og Syrien gjort det lettere for Irans arabiske rivaler at intensivere deres diplomatiske balancering af Iran (extern balancering). Det er ikke tilfældigt, at den nye amerikanske kurs er blevet ledsaget af saudiarabiske og egyptiske kampagner for at underminere Irans indflydelse i Syrien, Libanon og Palæstina, og af Marokkos beslutning om at afbryde de diplomatiske forbindelser med Teheran (Chubin 2009). Endelig vil Obama administrationens udstrakte hånd til Teheran også gøde jorden for øget diplomatisk pres og sanktioner, hvis Iran ikke viser vilje til at indgå i seriøse forhandlinger, men fortsætter med at trække tiden ud.

For det tredje har både Europa og de arabiske lande hidtil handlet i overensstemmelse med en afskrækkelsesog inddæmningslogik. Deres vilje til at træffe effektive foranstaltninger for at balancere iransk indflydelse er steget i takt med, at truslen er blevet klarere. Heraf følger, at EU og mange arabiske lande kan forventes, at ville støtte hårdere økonomiske sanktioner og øget diplomatisk isolation, hvis Iran fastholder sin kurs mod erhvervelse af atomvåben. GCC-landene og de amerikanske allierede i regionen må også forventes (under pres fra USA) at tilslutte sig tættere samarbejde med USA og de vestlige lande, ligesom de gjorde i 1990 som reaktion på Iraks angreb på Kuwait.

Endelig har de foregående års interne uroligheder i Iran ligeledes forbedret udsigterne til effektiv inddæmning og balancering af Iran. Det er gennem de seneste måneder blevet mere tydeligt, at præsident Ahmedinejad ikke er i stand til at reducere den igangværende magtkamp i Iran. Dette skyldes, at der er mange latente spændinger, der bliver mere og mere tydelige hos de nykonservative. Desuden har den voksende offentlige modstand imod regimet øget splittelsen i den nykonservative fløj, selv blandt de mest anerkendte figurer og præster. Flere og flere af de tidligere nykonservative allierede har vendt den åndelige leder Ayatolla Khamanei ryggen i kølvandet på det omstridte præsidentvalg i maj 2009. Her kan man nævne nogle af de fremtrædende Ayatollaher, der har taget vigtige skridt væk fra den nykonservative fløj ( $f x$ Saanei, Bayat Zanjani og Javadi Amoli). Sidstnævnte er en af Irans mest fremtrædende konservative præster. Han er for nyligt trådt tilbage som leder af fredagsbønnen i Qom efter at have kritiseret den voksende uro i landet. Udviklingen i Irans magtstruktur med en gradvis underminering af Irans fragmenterede og samtidig unikke teokratiske styreform, og den manglende evne til at etablere nye konventionelle autoritære styreforme, har ført til en øget intern elite-rivalisering i det iranske politiske system (Rahigh-Aghsan 2010). Den seneste års interne ustabilitet har ført til en øget opfattelse i USA's administration, af at en politik der fokuserer på at opnå et regimeskifte er realistisk mulighed, og kan fungere som en slags supplement for inddæmning og balancering af Iran. Som den iranske vinder af Nobelsfredsprisen og menneskerettighedsaktivist Shirin Ebadi udtrykker det;

„While economic sanctions and military interventions both are introduced at the cost of the Iranian people, but, in turn, imposing political sanctions on Tehran would put more pressure on governments and result in its isolation. ... International political pressure could be intended to isolate, downgrade, and expel Islamic regime from international fora, while simultaneously extending an open hand to the Iranian people“. ${ }^{3}$

Internationalt politisk pres vil næppe medføre signifikant ændring i præstestyrets atomprogram på kort sigt. Til gengæld vil det moderere Teherans adfærd og forhindre Iran i at forfølge proaktiv sikkerhedspolitik i Mellem$ø$ øten med hensyn til at støtte terrorisme. Hertil kommer, at regimemodstanderne i stigende grad bakker op om sanktioner og isolation, og der er en voksende intern efterspørgsel på international pres - præcis som det var tilfældet i Sydafrika i 1980erne. At der er opbakning internt $i$ et land for international pres på et siddende regime for en ændring af deres politik, anses generelt for at være en betingelse for succes. 


\section{En nuklear dominoeffekt i Mellemøsten er ikke uundgåelig}

Mange frygter, at et atombevæbnet Iran vil udløse et atomvåbenkapløb i Mellemøsten. Nogle hævder, det allerede er begyndt. Ifølge denne tese vil Saudi-Arabien føle sig tvunget til at følge trop, hvis Iran bliver atombevæbnet. Dette vil yderligere lægge pres på Egypten, der ønsker at bevare sin (selvopfattede) status som leder af den arabiske verden, hvilket så vil presse Tyrkiet, som også stræber efter regional stormagtsstatus, og så fremdeles. Risikoen for et våbenkapløb er reel. Det understreges af, at 13 lande i Mellemøsten siden 2006 har bebudet nye eller genoplivet gamle planer for atomprogrammer (Taheri 2009). Men faren for et våbenkapløb er ikke umiddelbar. Tidshorisonten for disse planer ligger i størrelsesordenen 10-15 år. Dette giver USA tid til at tale Saudi Arabien, Egypten og Tyrkiet fra at blive atombevæbnede lande og USA har gode kort på hånden: USA kan folde sin atomparaply ud over disse lande og afkræve at de ikke selv udvikler atomvåben, hvis de fortsat vil have USA's militære, økonomiske og politiske støtte. Denne taktik fungerede i en tilsvarende situation med Taiwan og Sydkorea under den kolde krig, og der er ingen grund til, at dette ikke skulle kunne gentages i Mellemøsten (Foran og Spector 1997). Det forhold at Iran, med sine ballistiske missiler, ikke er i stand til at nå mål i USA, resulterer i at den nukleare trussel fra USA, er mere troværdig i den Persiske Golf, end den var i Vesteuropa under den Kolde Krig.

\section{Konklusion}

Antagelsen om Irans voksende magt er uholdbar og mindre truende end de fleste eksperter antager. Irans styrkede magtposition har i vid udstrækning været forårsaget af faktorer, som Iran ikke selv kontrollerer, nemlig: det amerikanske regimes politiske skift i Mellemøsten, høje oliepriser og den israelsk-palæstinensiske konflikt. Teheran har nydt godt af andre lande, og udnytter de meget gunstige ydre omstændigheder til at placere sig som en 'spoiler' i alle regionale konflikter i Mellemøsten (Rahigh-Aghsan og Viggo Jakobsen 2010). Hård magt og blød magt tilgange har ret i, at Iran kan stikke en kæp i hjulet i stabiliseringsbestræbelserne i Afghanistan, Libanon, Irak, og Palæstina, og at Iran skal have en plads ved bordet, når disse spørgsmål bliver diskuteret. De tager fejl, når de argumenterer for, at Iran er i stand at gennemtrumfe sin vilje i alle sikkerhedspolitiske spørgsmål i regionen. Irans faldende indflydelse i Irak er en klar indikation heraf (Bramming 2010, 6).

Samtidig vil Irans evne til at forme og bestemme resultater i Den Persiske Golf og Mellemøsten, yderligere/ tilsvarende blive reduceret $\mathrm{i}$ takt med interne politiske oprør og den splittelse, der har gjort sig gældende siden præsidentvalget i sommeren 2009. Dette vil gøre det sværere for Teheran at føre en sammenhængende og proaktiv udenrigs- og sikkerhedspolitik, der yderligere vil blive reduceret ved en vedvarende og sammenhængende indsats under ledelse af USA. Men selvom Iran er mindre magtfuld og mindre truende end man antager, bør regimet i Teheran stadig tages alvorligt. Iran har øget sin relative magt, samt spillet en destabiliserende rolle i Irak, Libanon, og Palæstina, og det har helt sikkert kapacitet til at forsætte med at gøre det fremover.

\section{Referencer}

Abu-Nasr, Donna 2009, 'Saudi government cracks down on Shiite dissidents', The Associated Press, March 29, 2009.

Bennhold, Katrin 2008, 'France gains military presence in Persian Gulf', International Herald Tribune, January 16.

Bramming, Pernille 2010, 'Ny alliance', Weekendavisen årgang $262 \mathrm{nr}$. 21, 28. maj-3. juni 2010, p. 6.

Carter, Ashton B. and Perry, William J. 2006, 'Plan B for Iran: What If Nuclear Diplomacy Fails?', The Preventive Defense Project, Harvard and Stanford Universities.

Chubin, Shahram 2008, 'Iran's 'Risk-Taking' in Perspective', Proliferation papers, 21 Winter 2008.

Chubin, Shahram 2009, 'Iran's Power in Context', Survival, vol. 51, no. 1, February/March, pp. 172-174.

Jentleson, Bruce W. 2007, 'Sanctions Against Iran: Key Issues', The Century Foundation Report, pp. 1-41.

Cordesman, Anthony H. 2008, 'Security Cooperation in the Gulf: Actions Rather than Words and Good Intentions', Washington DC: CISI.

Eisenstadt, Michael 2001, 'The Armed Forces of the Islamic Republic of Iran: An Assessment', Middle East Review of International Affairs, 5:1, Article 2.

Etzioni, Amitai 2010, 'Can a Nuclear-Armed Iran Be Deterred?', Military Review 90:3 (May-June 2010), pp. 117-125.

Fitzpatrick, Mark 2008, 'Framing the Problem: Iran's Pursuit of Fissile Material', International Institute for Strategic Studies (ISS), Adelphi Papers 12 December 2008.

Foran, Virginia I., and Spector Leonard S. 1997, 'The application of Incentives to Nuclear Proliferation' in David Cortright (ed.) The prise of Peace: Inducement Strategies for International Conflict prevention, Lanham, Md.: Rowman and Littlefield.

Global Research, 2010, http://www.globalresearch.ca/index.php?context=va\&aid=19049

Gosselin, Trevor P. 2009, Iran in Perspective: Menacing or Misunderstood?', Canadian Forces College, Masters in Defence Studies Research Paper 35.

IAEA 2008, Implementation of the NPT Safeguards Agreement and relevant provisions of Security Council resolutions 1737 (2006), 1747 (2007), 1803 (2008) and 1835 (2008) in the Islamic Republic of Iran, GOV/2008/59, November 19, 2008, para. 15-16.

IISS 2009, 'Iran's missile development', Strategic Comments, vol. 15, no.1, February 2009

Inbar, Efraim 2006, 'The Need to Block A Nuclear Iran', Middle East Review of International Affairs, 10:1, Article 7. 
Jentleson, Bruce W. 2007 'Sanctions Against Iran: key Issues', The Century Foundation Report.

Green, Jerrold D., Wehrey, Frederic and Wolf, Charles 2009, 'Understanding Iran', Santa Monica, CA: RAND, pp. 34-36.

Lowe, Robert and Spencer, Claire 2006, 'Iran, Its Neighbours and the Regional Crises', London Chatham House, A Middle East Programme Report, pp. 1-49.

Katzman, Kenneth 2008, 'Iran's Activities and Influence in Iraq', CRS Report for Congress, October 21, 2008.

Lee Myers, Steven 2008, 'Iran poses threat to global security, Bush says', The New York Times, published Sunday, January 13. 2008 see http://www.nytimes.com/2008/01/13/world/americas/13ihtprexy.5.9183009.html.

Malmvig, Helle, Breaking Views: Obama og Mellemøsten: USA’s magt på retur, Weekendavisen 22.0120101 . SEKTION side 9.

Maloney, Suzanne 2007, 'Fear and Loathing in Tehran', National Interest, Issue 91 September/October 2007, pp.42-48.

McInnis, Kathleen J. 2005, 'Extended Deterrence: The U.S. Credibility Gap in the Middle East', The Washington Quarterly, 28:3, pp.169186.

Nasr, Vali 2004, 'Regional Implications of Shi'a Revival in Iraq', The Washington Quarterly, 27: 3, pp. 10-15.

Nasr, Vali 2007, 'The Shia Revival', The Military Review, 87:3, pp.9-13.

Nawaf, Obaid 2006, 'A Shia Crescent and the Shia Revival: Myths and Realities', Saudi National Security Assessment Project, p. 9.

Nye, Jr., Joseph S. 1990, 'The Changing Nature of World Power', The Political Science Quarterly, 105:2, pp.177-192.

Pollack, Kenneth M., Byman, D.L., Indyk, M., Maloney S., O'Hanlon, M.E., and Riedel B. 2009, 'Which Path to Persia?' Options for a New American Strategy Toward Iran', Brookings Institution Press, Washington DC.

Posen, Barry 2006, 'A Nuclear-Armed Iran A Difficult But Not Impossible Policy Problem', The Century Foundation Report, pp.1- 28.

Rahigh-Aghsan, Ali 2010, 'Iran Prestestyret - under udvikling eller afvikling?', Ræson 2. årgang nr. 12, 21 april 2010, pp. 10-13.

Rahigh-Aghsan, Ali and Jakobsen, Peter Viggo 2010, 'The Rise of Iran: How Durable, How Dangerous', The Middle East Journal, Autumn 2010, 64:4, pp. 559-573

Rubin, Barry 2006, 'Iran: the rise of a regional power', The Middle East Review of International Affairs, 10:3, pp.142-151.

Sagan, Scott Waltz, Kenneth and Betts, Richard K. 2007, 'A nuclear Iran: Promoting Stability or Courting Disaster?', Journal of International Affairs, 60:2, pp.135-150.
Sagan, Scott D. 2006, 'How to Keep the bomb From Iran', Foreign Affairs 85:5, pp. 45-59.

Salem, Paul 2007, 'Dealing with Iran's Rapid Rise in Regional Influence', The Japan Times, February 22.

Schake, Kori and Yaphe, Judith S. 2001, 'The Strategic Implications of A Nuclear-Armed Iran', Institute for National Strategic Studies, National Defense University Washington DC. McNair Paper 64, pp.1-79.

Tabnak online news 2009:

http://www.tabnak.ir/pages/?cid=19816, September 2, 2008 (assessed May 28, 2009).

Taheri, Amir 2009, 'Iran Has Started a Mideast Arms Race', Wall Street Journal, 23. marts 2009.

Takeyh, Ray 2008, 'Iran's New Iraq', The Middle East Journal, 62:1, pp. 13-30.

Talmadge, Caitlin 2008, 'Closing Time Assessing the Iranian Threat to the Strait of hormuz', International Security, 33:1, pp.82-117.

Yavuz, M. Hakan 2009, 'Secularism and Muslim Democracy in Turkey', Cambridge University Press.

Ward, Steven R. 2005, 'The Continuing Evolution of Iran's Military Doctrine', The Middle East Journal, 59:4, pp. 559-576.

Waltz, Kenneth N. 1979, 'Theory of International Politics', AddisonWesley Publishing Company.

Whitehouse, 2010, see http://www.whitehouse.gov/the_press_office/ Remarks-By-President-Barack-Obama-In-Prague-As-Delivered/; http://www.thetotalcollapse.com/iran-nuclear-issue-the-top-globalsecurity-threat/.

\section{Noter}

1. Særlig tak for konstruktive bidrag til Peter Viggo Jakobsen, Kennet Lynggaard, Kristine Juul og Emilie Holm Johansen.

2. De to perspektiver bruges her som idealtyper for at præsentere deres forskellige logikker så klart som muligt. Flere forskere bruger både hård og blød magtskomponenter i deres argumentation, og forskere placeret indenfor de to perspektiver bruger ikke nødvendigvis alle de argumenter, som de to perspektiver tillægges.

3. Se Shirin Ebadi pres conference i Deutsche Welle (13.07.2009), http://www.dw-world.de/dw/article/0,,4486346,00.html. 